\title{
Tributes to cardiac surgical pioneers
}

\author{
Lawrence H. Cohn, MD
}

\section{"The only way to predict the future ... is to invent it yourself."}

\section{—Norman E. Shumway, Jr}

In this issue, you will notice an interesting article that should have been printed 24 years ago: the presidential address of Norman E. Shumway, Jr, the 67th president of the American Association for Thoracic Surgery. His address titled, "Some thoughts from the other side of the table, or the last presidential address" is one of great insight, humor, and education. This address has been lying fallow for some time because it was never really completed and had some interesting sections that required carefully editing. His daughter, Dr Sara Shumway, a cardiac surgeon at the University of Minnesota, did a great job editing her father's manuscript and was in favor of us publishing this article similar to every presidential address in the past. Also accompanying the address is a career summary of Dr Shumway by Dr James Fann, presently a staff member of the Stanford University Medical Center Department of Cardiothoracic Surgery, as part of our monthly Presidential Perspectives series. Dr Shumway developed the heart transplantation operation and performed the first heart-lung transplant in the world with Bruce Reitz at Stanford Medical Center. I hope that our readership will enjoy this memorial to one of the great pioneers of cardiac surgery, Norman E. Shumway and benefit from his "last presidential address."

Another tribute to a pioneer in the field of cardiovascular surgery occurred on October 6, 2011, at Harvard Medical School. Dr Alain Carpentier, MD, of Paris, France, received the prestigious Warren Alpert Award from Harvard Medical School, which is Harvard's equivalent to the Nobel Prize and rewards bioengineering luminaries who have revolutionized the treatment of human health. Dr Carpentier was recognized for his pioneering efforts in the development of the bioprosthetic heart valve as well as the current concepts of mitral valve repair for myxomatous mitral valve disease. He and his wife, Sophie, developed a gluderaldehyde-based process that is the standard for bioprosthetic valve sterilization and connective tissue stablization. His fellow awardee that evening was Dr Robert Langer, Professor of Bioengineering at Massachusetts Institute of Technology and the most cited engineer in the world, who has made tremendous advances in drug delivery and tissue engineering. It was a superb evening honoring two biomedical giants who both richly deserved this honor.

A favorite quotation of mine is by Sir Isaac Newton, which characterizes these aforementioned gentlemen: "If I have seen further it is by standing on the shoulders of giants."

\footnotetext{
From the Division of Cardiac Surgery, Brigham and Women's Hospital, Boston, Mass.

Address for reprints: Lawrence H. Cohn, MD, Division of Cardiac Surgery, Brigham and Women's Hospital, 75 Francis St, Boston, MA 02115 (E-mail: lcohn@ partners.org).

J Thorac Cardiovasc Surg 2011;142:1295

$0022-5223 / \$ 36.00$

Copyright (c) 2011 by The American Association for Thoracic Surgery

doi:10.1016/j.jtcvs.2011.10.021
} 